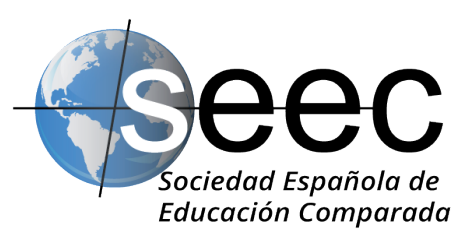

\title{
Building a Liberal Arts Tradition in India
}

Construyendo una tradición de artes liberales en India

\section{Takako Mino*}

DOI: 10.5944/reec.39.2021.30042

Recibido: 18 de febrero de 2021

Aceptado: 2 de junio de 2021

\footnotetext{
* TAKAKo Mino: is an adjunct lecturer at Ashesi University, Ghana. Her research interests include higher education in Africa, humanizing education, Ikeda/Soka Studies, and African indigenous education. Datos de contacto: E-mail: takakomino@gmail.com. ORCID: https://orcid.org/oooo-0002-5544-1618
} 


\begin{abstract}
Postcolonial nations often struggle with the legacy of higher education systems built by and for the benefit of former colonizers. In India, several visionaries endeavored to design new culturally relevant approaches to higher education while taking inspiration from the US liberal arts college model. In an interconnected world, where a broader scope of understanding is required to craft solutions to societal challenges, young Indians are seeking an alternative to the specialized university model typical of Indian higher education. This paper explores the practice of the liberal arts in India through three questions: How have Indian universities built their own liberal arts tradition? What tensions do these universities navigate? What can African countries learn from these examples? I collected data through document analysis and interviews with founders, faculty, students, and alumni at three new liberal arts universities in India. Reflecting the ideals of Indian indigenous thought, the universities empowered students to carve out their own path of self discovery while analyzing and developing a commitment to improving the Indian context. The universities faced numerous tensions: responding to pressures to produce highly employable graduates while remaining true to institutional ideals, balancing western and eastern traditions, and fostering greater inclusion while maintaining financial sustainability. The findings are relevant to African countries, who have a shared colonial experience with India and are seeking to create new culturally relevant education traditions.
\end{abstract}

Keywords: liberal arts; India; higher education; educational innovation; indigenous education; Africa

\title{
Resumen
}

Las naciones poscoloniales a menudo luchan con el legado de los sistemas de educación superior construidos por y para el beneficio de las antiguas colonias. En la India, varios visionarios se han esforzado por diseñar nuevos enfoques de la educación superior que se adapten a su contexto único, mientras se inspiran en el modelo universitario de artes liberales de EE. UU. En un mundo interconectado, donde se requiere un alcance más amplio de comprensión para diseñar soluciones a los desafíos sociales, los jóvenes indios buscan una alternativa al modelo universitario especializado típico de la educación superior india. Este artículo explora la práctica de las artes liberales en la India a través de tres preguntas: ¿Cómo han construido las universidades indias su propia tradición de artes liberales? ¿Cuales son las incertidumbres presentadas por estas universidades? ¿Qué pueden aprender los países africanos de estos ejemplos? Para ello, se recopiló datos a través de un análisis de documentos y entrevistas con fundadores, profesores, estudiantes y exalumnos de tres nuevas universidades de artes liberales en la India. Como reflejo de los ideales del pensamiento indígena indio, las universidades empoderaron a los estudiantes para que abrieran su propio camino de autodescubrimiento mientras analizaban y desarrollaban un compromiso para mejorar el contexto indio. Al mismo tiempo, las universidades enfrentaron numerosas inquietudes: respondiendo a las presiones para producir graduados altamente empleables sin dejar de ser fieles a sus ideales institucionales, equilibrar las tradiciones occidentales y orientales, y fomentando una mayor inclusión manteniendo la sostenibilidad financiera. Los hallazgos son relevantes para los países africanos, que tienen una experiencia colonial compartida con la India y buscan crear nuevas tradiciones educativas culturalmente relevantes.

Palabras clave: artes liberales; India; educación superior; innovación educativa; educación indígena; África 


\section{Introduction}

India is the world's largest democracy and home to the third largest higher education system in the world (World Bank, 2017, p. 82). Yet, no Indian university ranks among the top 200 universities in the Times Higher Education World University Rankings (Nanda, 2020). Many of the leading Indian universities were built by the British to train Indians for technical areas needed by the colonial administration; most Indian universities maintain a technical training model and reinforce a colonial epistemic frame (Batra, 2020). However, in the face of a rapidly growing and increasingly educated population, existing Indian higher education institutions lack the capacity to admit all qualified students (Nandrajog, 2016). Dissatisfied with the poor educational options available in India, 500,000 students go abroad for their studies every year (Sra, 2015).

Since the 1990s, many private universities were founded in India in response to the growing demand and now comprise 80 percent of the higher education system (Goyal, 2014). These include several liberal arts universities that have risen in popularity over recent years. One of Ashoka University's founders, Ashish Dawan explains the relevance of the liberal arts to India's needs as a society:
"What we need in India is not just economic change - what we need is societal transformation. It's about building a better democracy. You need people who are willing to question power, who are independent thinkers and who know how to write well and express themselves well in spoken form. India doesn't have enough of that". (Kazmin, 2018)

The liberal arts are not foreign to India. As the literature review section of this article demonstrates, many influential Indian thinkers advocated for a return to a multidisciplinary approach to education that is in line with ancient pedagogical practices of India. In a sense, the liberal arts is a rediscovery of Indian roots and the building of a new educational legacy adapted to the needs of modern India. These new liberal arts universities in India serve as educational laboratories for experimenting with innovative approaches to better prepare university graduates for the demands of a highly complex and interconnected world. Other emerging countries can learn from India as they navigate their own development paths rather than importing ideas from abroad or continuing education in the same way as their former colonisers. As an educator in Uganda, I wished to learn from India's example to support the development of higher education best suited for Uganda. It is important for countries - each with their own indigenous educational traditions - to create culturally appropriate systems for its own people.

This paper navigates the practice of the liberal arts in India through exploring case studies of three new liberal arts universities in India. The following research questions are explored in this study: How have Indian universities built their own liberal arts tradition? What tensions do these universities navigate? What can African countries learn from these examples? I begin with a literature review of indigenous Indian approaches to the liberal arts, the US liberal arts college model, and the relevance of the Indian experience to Africa. Then I present the findings, guided by the thinking of influential Indian educators, and provide an analysis of tensions. Finally, I conclude with recommendations for African countries seeking to develop new education traditions. 


\section{Literature Review}

This literature review first introduces the indigenous liberal arts in India with a focus on influential twentieth century Indian educators. Then, it will provide some background on the US liberal arts college model and explain why it has become the leading model for countries looking to establish the liberal arts. Finally, it will explain why the experience of Indian higher education is relevant to other postcolonial countries.

\subsection{Indigenous Liberal Arts in India}

India has a rich history of the liberal arts from its ancient past; Nalanda University of ancient India served as a hub for multidisciplinary educational exchange in Asia (Altbach, 2016). Buddhist, Hindu, and Islamic forms of education weave a vibrant tapestry of intellectual and spiritual traditions that reflect the multi-faceted history of India (Choudhary, 2008). However, these educational traditions were impacted by the advent of British education. This section highlights several twentieth century Indian thinkers, who re-imagined education in India for India: Rabindranath Tagore, Mahatma Gandhi, Jiddu Krishnamurti, and Sri Aurobindo. Their approaches centered on the interconnectedness of life, the holistic development of students, and relationships of care and trust between teacher and student. This integrated Indian approach to education will serve as the theoretical framework for this study.

These Indian thinkers saw the limitations of British colonial education in India. Tagore observed how British education created family discord by alienating children from their own culture (Gupta, 2002). “The Parrot's Training” (1924), satirized the dehumanizing Indian education system where children were force-fed disconnected information with no care for their happiness. Aurobindo noted that British colonial education ignored spiritual development, which was a vital component of life (Mohanty, 2019).

While drawing inspiration from ancient Indian philosophy, the thinkers created schools that helped students reconnect to their cultural roots. Tagore founded the Santiniketan school to create an educational experience for students grounded in Indian culture and the natural environment. Tagore sought to make the ideal of a united humanity a reality at the school. At Tagore's school, students took classes in theater, dance, and literature, which sparked their imagination and developed their Indian identity (Gupta, 2002). Students explored the intellectual traditions of both India and the West, and rural and urban students engaged in educational exchange (Gupta, 2002). Tagore and Gandhi shared a learner-centered educational approach that was rooted within the social and natural environment in order for children to live value creating lives (Sharma, 2021).

Gandhi led a unifying educational revolution for the ordinary people as part of the Indian independence movement. Gandhi's practice and teaching of satyagraha, or nonviolent resistance, reflected the absolute trust in humanity that he had forged through rigorous introspection (Ikeda, 1996). Gandhi's nai talim, or basic education, was based on the principle that work and knowledge were inseparable - Gandhi advocated for village-based schools in mother tongues where students also underwent manual training (Sykes, 1988). Gandhi made handicrafts - the expertises of the lower castes - the center of his pedagogy; he believed this was the ideal way for children to learn and would pave the way for a more equal new social order (Sykes, 1988).

The schools founded by these thinkers modeled a teacher-student relationship based on care. Rather than teaching children to memorize facts and to think within the 
constraints of the curriculum, children were trusted to take ownership of their learning; the role of the teacher was to cultivate the student's soul by drawing out and perfecting the unique innate potential of each child instead of molding students into what the teacher envisioned (Banerjee, 2013). At Aurobindo's school, students received progress reports with comments on ability, industry, interest, and overall progress instead of marks; students could choose whether to listen to a lecture or to study on their own at the library (Mohanty, 2019). Krishnamurti saw education's purpose as "bring[ing] about an integrated individual who is capable of dealing with life as a whole" (p. 24) and opposed the use of rewards and punishment for children (Krishnamurti, 1953). All of these Indian thinkers advocated for a holistic education that not only helped students obtain knowledge but shaped their emotional and spiritual development.

\subsection{US Liberal Arts College}

Resonant ideas were expressed in many of the educational traditions of Europe and the US, and several new Indian universities looked to adapt the US liberal arts college model. In many ways, the US liberal arts model, which is intertwined with American ideals of democracy, has become the model for other countries looking to establish the liberal arts (Rothblatt, 2003). The US can find the origin of its liberal arts in ancient Greek philosophers (Nussbaum, 1998) and medieval European universities (Roche, 2013), but after WWII, many European universities adopted an approach of early specialization from the undergraduate level (Van der Wende, 2011). Some European countries have sought more flexible alternatives and turned to the American model of the liberal arts for inspiration (Van der Wende, 2011).

The US liberal arts college is usually small, residential, and characterized by extensive student and faculty interactions (Breneman, 1990). Liberal arts colleges emphasize good teaching and a broad-based education rather than a career-focused education. According to the Association of American Colleges and Universities (AACU) (2014), the liberal arts is defined as

"an approach to learning that empowers individuals and prepares them to deal with complexity, diversity, and change. It provides students with broad knowledge of the wider world (e.g., science, culture, and society) as well as in-depth study in a specific area of interest".

The four essential learning outcomes of liberal arts education as articulated by the AACU (2020) are the following: students gain a knowledge of human cultures and the world through studies across the disciplines on the big questions facing humanity; students develop intellectual and practical skills through progressive practice; students develop personal and social responsibility rooted in diverse communities and real-world challenges; students engage in integrative and applied learning required to understand and tackle complex problems.

However, the liberal arts college faces major challenges to its survival in the American context. Many liberal arts colleges have had to close or move towards a more careerfocused approach because of failing to maintain the high costs of small classes and individualized learning experiences (Cohn, 2019). On the other hand, liberal arts education has been increasingly popular within the Asian context; several major East Asian universities made attempts to incorporate the liberal arts into their curricula. Yang (2016) critiques these endeavors as an imitation of Western models rather than an adaptation 
to the Asian context. While some literature explores the practice of the liberal arts within the East Asian context, there is scant literature on the liberal arts in India.

\subsection{India and African Countries}

India's experience in adapting and developing its own liberal arts tradition is relevant to postcolonial African countries. Similar to most African countries, India's modern higher education system reflects a strong colonial legacy. During colonial rule, British-style universities were established to create a professional class of Indians to serve the needs of the colonial administration (Choudhary, 2008). In 1854, three universities were established that were modeled after and affiliated with the University of London (Choudhary, 2008). Subsequently, many colleges were established as affiliates to these three universities, meaning that they taught the same curriculum, gave the same exams, and awarded the same degrees. Since then, thousands of institutions have been built in India, but the quality of higher education has been inconsistent due to poor regulation and corruption (Agarwal, 2006).

In Africa, many of the prestigious public universities were built by former colonizers and modeled after Western institutions; therefore, African universities face the challenge of creating a humanizing education that incorporates indigenous thought and empowers students to flourish in their own potential (Mino, 2020a). In former British colonies like Ghana, universities were established under affiliation with the University of London. The accreditation standard set by existing public universities that have followed the London model often stifles the ability of new universities to innovate (Mino, 2020b). Analyzing Indian liberal arts universities' approach, experience, and challenges will be of use to educators in African countries that are also striving to create a more fulfilling education for African students.

\section{Methods}

The three case study institutions - Ashoka University (Haryana), Symbiosis International University (Maharashtra), and Azim Premji University (Karnataka) - were selected for their diverse approaches to the liberal arts and accessibility. I conducted semi-structured online interviews with key informants, including 1 founder, 5 faculty members, and 10 students and alumni. I collected background information through university websites and other publications. I analyzed the interviews for common themes to enrich understanding of the liberal arts in India.

\subsection{Case Study Universities}

\subsubsection{Ashoka University}

Ashoka's story weaves together the aspirations of several first-generation entrepreneurs who wished to build an internationally competitive university. Yale graduate Ashish Dawan and Sanjeev Bikchandani sought advice from Pramath Sinha, founding Dean of India School of Business Hyderabad and University of Pennsylvania alumnus, on their vision for establishing a top-notch college in India. Around the same time, Sinha was approached by several India Institute of Technology alumni about starting a Nobellaureate-producing engineering college. Sinha brought together the two groups to found 
a new liberal arts university. Ashoka raised over $\$ 100$ million from 101 founders, which made Ashoka the biggest collective philanthropy effort in India's history (Kazmin, 2018). Under its collective governance system, each founder is limited to one seat on the board, which prevents anyone from exerting excessive influence over decision-making and ensures academic independence (Kazmin, 2018). In 2011, the team tested out their idea through its flagship program, the Young India Fellowship (YIF), a one year liberal arts post graduate diploma program. Faculty from elite universities across the globe were recruited to teach at YIF. The success of YIF and its graduates led to the establishment of the Ashoka undergraduate program in 2014. Ashoka's mission is to "[c]reate a global fellowship by nurturing a talented pool of young people and prepare them to think critically, communicate effectively and become leaders with a commitment to public service for an intellectually curious, self-aware, and impactful life ahead" (Ashoka, 2020). Ashoka offers 20 majors, including Biology, Economics, English, History, Mathematics, Philosophy, and Psychology.

\subsubsection{Symbiosis International University}

Symbiosis International University was deemed as a university in 2002. Renowned botanist and Padma Shri recipient, S. B. Mujumdar founded the Symbiosis Society and eventually the university. The origins of the university can be traced back to Mujumdar's support to African students based in Pune. African students felt discriminated against in Indian society and struggled in their studies because they did not know English well. Mujumdar decided to teach them English in his home for free. Eventually, so many African students joined the classes that he started an English language institute for international students. As he spent more and more time with these students, Mujumdar eventually decided to start a law school so that African students could study British law and return to their countries to find jobs. Eventually the school gained university status and continues to welcome international students from 85 countries. Symbiosis started India's first 4 years bachelors of arts and science degree programs in 2011 and established the Symbiosis School of Liberal Arts (SSLA) under the Faculty of Humanities and Social Sciences. The liberal arts program founding faculty drew inspiration from US liberal arts colleges and visited DePaul University College of Liberal Arts and Sciences to learn from their model. The university's motto comes from Vedic thought: "Vasudhaiva Kutumbakam," meaning "World is one family" (Symbiosis, 2020). Students graduate with a liberal arts and sciences degree with major specializations such as Computer Studies, Economics, Sociology, Anthropology, Media Studies, Business Studies, and Political Science \& Public Policy.

\subsubsection{Azim Premji University}

Azim Premji University was founded in 2010 with a vision of education for social change (Azim Premji, 2020c). Business tycoon Azim Premji was inspired by Gandhi's socioeconomic philosophy of trusteeship; this was the idea that the wealthy should establish trusts to support the welfare of the poor. He decided that he wanted to dedicate most of his wealth to contributing to India's development and put over two-thirds of the stocks in his company to philanthropy (Arakali, 2021). In 2001, he founded the Azim Premji Foundation to fund community-based development work; the foundation established Azim Premji University to help tackle the challenges in the education and development 
sectors (Azim Premji, 2014). Like the foundation, the university makes an explicit commitment to creating a more just, equitable, humane, and sustainable society; collaboration between its students and faculty and the foundation are designed to be mutually enriching (Azim Premji, 2014). The school develops in students the attitudes, values and the capacity for self-understanding through the incorporation of reflection as part of the key pedagogies, and 60 percent of graduates go on to work in the social sector (Azim Premji, 2020a). Nearly half of the students come from small towns and rural areas (Azim Premji, 2020a). Research is socially focused on the challenges facing marginalized communities in India, and an annual research conference is convened to debate issues related to education and development in India. Azim Premji offers the following undergraduate majors: Physics, Biology, Mathematics, Economics, English, Philosophy, and History.

\section{Results}

This section presents the findings from the interviews based on shared attributes of the ideal education outlined by the twentieth century Indian thinkers: the interconnectedness of life, holistic development, and relationships of care and trust. This study had a limited sample size due to the inability of the author to visit India during the pandemic. While the findings cannot be said to be representative of all liberal arts universities, they offer some valuable insight.

\subsection{Interconnectedness of Life}

The multidisciplinary nature of the liberal arts core curriculum enabled students to understand and appreciate the interconnectedness of all aspects of life while being grounded in the local context. At all three universities, students were required to study the Indian context through a foundational course on Indian society and through Indian case studies in other coursework while studying international modes of thought. This is similar to how Tagore and Aurobindo developed students' Indian identity through study in the mother tongue and study of both eastern and western knowledge (Banerjee, 2013). At Ashoka, this was the "Indian civilizations" course, which introduced students to important influences on Indian civilizations from prehistoric times to the present with an emphasis on the diverse religions, cultures, and philosophies that have shaped India. At Azim Premji and Symbiosis, the course was called "Understanding India." Some of the faculty devised creative ways to teach students about India through unconventional topics. An elective course at Symbiosis explored the story of India through its food, introducing students to the country's diverse culinary traditions. According to a faculty member, these courses helped students appreciate Indian philosophy rather than thinking about India as a place where "there was nothing nice." Students became more invested in India's future instead of looking to escape India.

Foundational courses taught students the essential habits of mind to help students understand and analyze cross-cutting issues in depth. This is similar to how Gandhi's satyagraha equipped ordinary people with the skills to think critically, introspect, and develop creative wisdom in the pursuit of a more just society. At all three universities, students developed the skills necessary for becoming contributive citizens, who can address the challenges facing India and beyond. At Azim Premji, the core course "Public reasoning" introduced students to debates, argumentation, and controversy and equipped them to understand discussions in the public sphere. Other core courses consisted of 
critical reading and writing, quantitative methods, and creative expressions. At Ashoka, first year students took two seminar courses in critical thinking and were required to take core courses in the following categories: great books; literature and the world; Indian civilizations; environmental studies; mind and behavior; economy, politics, and society; mathematical thinking; and principles of science. At Symbiosis, students developed their foundational and interdisciplinary skills through core courses including writing, legal awareness, history of ideas, short stories from around the world, environmental studies, IT fundamentals, quantitative methods, research methods, and economic analysis. Beyond the core, students were encouraged to study a variety of courses and to draw connections between different subject areas that they never realized were related.

\subsection{Holistic development}

All three universities sought to holistically develop students into empathetic and capable people, who can shape a better world. Appreciating the interconnected nature of the world requires the ability to think and develop one's own understanding of various issues rather than being told what to believe like the miserable parrot in Tagore's "Parrot's training." At Azim Premji, reflection was a core part of the learning process. Most courses required students to keep a learning journal, where they write reflections about their learnings. Students were encouraged to develop an "openness towards being corrected and revised" rather than being closed off to other views. The faculty sought to prepare thoughtful people who would seek to research and understand social issues as much as possible before taking action - they recognized that solutionism could lead to a patronizing attitude and create more problems in the long run.

Rather than memorizing disconnected bits of information, students shared that they were taught in a way that made them realize much more about their own lives and their ability to make a contribution to society. Some Ashoka students shared about how they became more aware of social issues and developed a sense of personal responsibility to take action to tackle these issues. This is the emotional development that the Indian thinkers called essential in education. One of the international students said that he didn't really care about social issues before, but "I am more of a social justice warrior now." Because of his education, he now notices injustice when it happens and feels compassion for those who are being treated unfairly. A Dalit student from the untouchable class spoke about how he felt he could be at an equal footing at Ashoka's campus and realized the importance of sharing his experience as a Dalit with others. He even expressed how he felt about these issues openly in class and helped other students become aware of the Dalits' challenges. Several of the students coming from the upper class spoke about how they came from a privileged background and were not even aware of societal issues affecting others. But now they actively follow the news on their own initiative and think about how to use their privilege to help others. For instance, when the citizenship amendment act was enacted in 2019, the student government led a 2-day discussion about the issue and organized protests. Yet, this new awareness came with challenges. An alumna said that she had many quarrels with her parents about her opinion on social inequities that she learned about from Ashoka. Students' minds were opened to social injustices from their liberal arts education, but eventually, they returned to their families and the wider society that often held very different perspectives about those issues. 


\subsection{Relationships of Care and Trust}

Like the Indian thinkers in the literature review, each university sought to build a sense of community based on tight knit relationships of trust and care. Azim Premji was intentional about developing close student-faculty relationships in order to "create rich emotionally dense experiences." It is common to see faculty and students spending time and eating meals together. Each student is paired with a faculty mentor, who meets with them twice a month. Having someone to speak to goes a long way in breaking down barriers - during these mentoring sessions, students can ask questions and feel less out of place. Symbiosis also has highly relational origins - the founder wished to make the international students feel welcome in India and took the initiative to teach and support them. The students loved and appreciated this experience so much that it became an institution. At Ashoka, faculty also closely interact with students within the small class sizes, and students bond by talking together late into the night and engaging in club and sports activities. While this relational element may not seem to directly relate to learning outcomes, it compliments the outcomes. This is because when students feel a sense of belonging to the community, they can develop the confidence to participate in the classroom and express their diverse viewpoints. They also learn how to develop personal and social responsibility through observing the example of the faculty members. However, the spiritual element expressed in many Indian thinkers' philosophies did not feature strongly in all of the schools - all of them were committed to a secular education while helping students gain exposure to India's rich history and philosophy through an analytical viewpoint.

Students saw the liberal arts as a unique opportunity to be trusted in their own journey of discovery. The ideas expressed resonate with Indian thinkers such as Krishnamurti, who emphasized freeing the mind, and Aurobindo, who trusted students to choose how they learned in his school. The word "explore" was mentioned in many interviews. One student said that it was an "opportunity to explore more disciplines than just a degree." Students who were confused about what they wanted to do were able to gain clarity through the exposure to different disciplines. The focus was on learning rather than on selecting a career track. After experiencing a more rigid pre-tertiary education system, the liberal arts was a liberating experience for the students. This was significant since at other universities, students were limited in terms of the majors they could select based on their marks. With this freedom also came a development of self-awareness. A student explained that the liberal arts for him was "more about developing your own personality." Another student noted that "learning about myself was the biggest thing I've learned at Ashoka." One student said that he had come to Ashoka with a money-oriented mindset and had planned to pursue economics, but after taking a psychology class, he discovered his passion for psychology and decided to major in it. Empowering students to carve out their own paths of self-discovery rhymed closely with the education visions of Indian thinkers.

\section{Discussion}

\subsection{Practical yet Idealistic}

The findings from the universities shed light on the tensions faced by these institutions. One is handling parents' expectation of universities to prepare students for successful careers while upholding core institutional values, such as citizenship and societal impact. 
The practical imperative of producing employable graduates was very important in a society where higher education was viewed as a ticket to social mobility. According to all 8 interviewed students, the "liberal arts" as a term was not familiar to many in Indian society, and many parents and students were concerned about the practical application of the liberal arts to future employment. Many focused on the "arts" part of liberal arts and did not know that liberal education also included the sciences. Batra (2020) argues that education in India has become even more instrumentalized during the Covid-19 pandemic, where only the knowledge deemed useful is taught in the limited teaching that can be accomplished on digital platforms - this instrumental approach often excludes access to and the contributions of marginalized groups. Similarly, universities must meet the demands of stakeholders with varying expectations while maintaining the flexibility to innovate in a way that is true to their ideals. One step that has bolstered the liberal arts in helping to make it more mainstream is the government's inclusion of the liberal arts in its 2020 National Education Policy.

The national policy document invokes India's historical roots in liberal education dating back to the ancient universities of Takshashila and Nalanda, and it explains that students must be broadly educated across the disciplines while developing a specialisation in order to be prepared for the needs of the 21st century. The liberal arts was a key part of the higher education reform presented in the document. Since objectives endorsed by the government tend to get greater traction, this was welcome news. However, former director of the National Council of Education Research and Training, Kumar (2019) expresses his concern that this may only promote the liberal arts without liberalism. He describes "liberal" as udaar, or large-hearted, in Hindi, meaning that schools need to help students develop tolerance and become open-minded in listening to others' perspectives. An interdisciplinary education is not enough in promoting a spirit of liberalism. Liberal arts institutions are supposed to be bastions of pluralism and openness. How can universities promote open-minded dialogue in a politically polarized climate? This is another tension faced by universities.

\subsection{Balancing East and West}

Universities must exercise creativity and wise judgment to adapt the liberal arts approach to the Indian context while learning from institutions abroad. Since India has its own tradition of the liberal arts dating back to ancient times, these universities can lead further efforts to infuse the rich wisdom that already exists within India in the process of building their own unique liberal arts traditions. The challenges of uncovering indigenous knowledge and including them into formal education are complicated in a country as diverse as India, which has 22 official languages, 6 regions, and many officially recognized religions. There is still much more work to be done in the realm of research to document, analyze, and apply many aspects of India's indigenous thought to education.

While the Indian liberal arts universities reflected many of the ideas of Indian thinkers, future research could delve further into how to actively engage with educational philosophy of Indian thinkers in class and practically actualize them in higher education. This may also help with bridging the disconnect that students feel between what they learn at university and what they find in broader Indian society. Studying these roots will enable the students to have a better understanding of why people think in a certain way and strive to look at societal issues from multiple perspectives. At the same time, students need to understand the world beyond the western civilizations that dominate 
most academic disciplines in order to truly develop a global orientation - this is another great balancing act that the universities will need to undertake in fostering students who can make an impact on India and in the world.

\subsection{Quality and Inclusion}

Third, there is a tension between providing a high quality, individualized education while ensuring inclusion. It makes a tremendous difference when those who have directly experienced the societal issues being studied are a part of the classroom conversation, as it was reflected in the example of the Dalit student. At a tuition rate of $\$ 6600$ a year where gross national income per capita income is $\$ 6900$, Ashoka has been criticized for being unaffordable for most Indians. One Ashoka student asserts that Ashoka was a university built by the most privileged for the elite while citing the lack of diversity in his YIF cohort (Rao, 2020). While concerns about inclusion are valid, providing more scholarships requires significant resources and careful planning in order to maintain financial sustainability. This may mean admitting a greater number of students with the same resources. Although education could be made more affordable, such a move could compromise the quality of education. Ashoka does provide need-based financial aid, and about half of the students benefit from some kind of aid (Ashoka, 2021). Still, to make this kind of education accessible for a much wider population may be challenging. SSLA (2021) faces this challenge with a tuition rate of $\$ 5500$ a year and few scholarships available. Azim Premji (2020b) was the most affordable of the three with a tuition rate of $\$ 3900$ and offers need-based scholarships to students from low-income families. Future researchers can learn from the universities that have kept their costs low while maintaining quality or that have innovative funding schemes since the cost of this high quality liberal arts education remains a barrier to most of the population.

\subsection{Recommendations for African Countries}

Some lessons for African countries that are forging their own educational philosophies emerge from the experience of Indian liberal arts universities. First, when drawing inspiration from other educational models, it is important to adapt that model to the unique context of the country. Rather than importing models that may have worked in other places, building upon one's own cultural legacies can create new educational traditions that are practical and relevant to today's young people. This includes nurturing a sense of pride and identity among the students about their country. Educators should challenge themselves to design refreshing curricula that enable students to appreciate the richness of their own unique context and to think about what they can do to contribute to it rather than escape from it. Scholars can uncover the indigenous educational traditions of the country and think about ways that it could inspire educational innovations. The application of Ubuntu to education is already beginning to be explored (Le Grange, 2012; Mino, 2020a; Mino \& Heto, 2020). In addition, African universities will need to navigate the tensions presented in the discussion of raising both transformative leaders and employable graduates, of integrating both African and other forms of knowledge into education, and of innovating ways to make quality education affordable. Tackling these challenges creates an invaluable opportunity to develop the kind of education that will propel the sustainable development of emerging countries. 


\section{Conclusion}

Indian liberal arts universities have created an empowering educational experience for students to explore multiple disciplines, develop a greater appreciation of the Indian context, and unlock their potential through supportive relationships with others - as a result, these institutions have become hugely successful in India. These lessons from India are of relevance to education in African countries because of shared experiences as former European colonies. These African countries can learn from the Indian example in thinking about how to help students explore their own potential and develop a sense of responsibility to improve their countries. Building a new educational tradition requires the joint efforts of diverse stakeholders in a society and the tenacity to navigate the challenging tensions that accompany the task. However, taking on this noble task of carefully rethinking and redesigning the education of young people is critical in building a more dignified, integrated, and human society.

\section{References}

Agarwal, P. (2006). Higher education in India: The need for change. Working paper.

Altbach, P. G. (2016). The many traditions of liberal arts-And their global relevance.

International Higher Education, 84, 21-23.

Arakali, H. (2021, March 9). FILA 2021 best philanthropist-promoter: Azim Premji, the generous giver. Forbes India. https://www.forbesindia.com/article/leadershipawards-202021/fila-2021-best-philanthropistpromoter-azim-premji-thegenerous-giver/66871/1

Ashoka University. (2021). Financial aid. Ashoka University. https://www.ashoka.edu. in/financialaid

Association of American Colleges \& Universities. (2014, April 18). What is liberal education? https://www.aacu.org/leap/what-is-liberal-education

AACU. (2020, April 30). Essential learning outcomes. https://www.aacu.org/essentiallearning-outcomes

Azim Premji University. (2014). Origin and purpose. http://azimpremjiuniversity.edu. in:80/SitePages/origin-and-purpose.aspx

Azim Premji University. (2020a). Educational philosophy. http://azimpremjiuniversity. edu.in:8o/SitePages/educational-philosophy.aspx

Azim Premji University. (2020b). Fees and scholarships. https://azimpremjiuniversity. edu.in/SitePages/admissions-programme-ug-programme.aspx

Azim Premji University. (2020c). Vision and mission. Retrieved October 8, 2020, from http://azimpremjiuniversity.edu.in:80/SitePages/vision-mission.aspx

Banerjee, D. (2013). The theory of education in the light of Aurobindo and Tagore. Periodic Journal, 1(3), 220-225. 
Batra, P. (2020). Re-imagining curriculum in India: Charting a path beyond the pandemic. PROSPECTS. https://doi.org/10.1007/s11125-020-09518-6

Breneman, D. W. (1990). Are we losing our liberal arts colleges? AAHE Bulletin, 43(2), 3-6.

Choudhary, S. K. (2008). Higher education in India: A socio-historical journey from ancient period to 2006-07. The Journal of Educational Enquiry, 8(1).

Cohn, S. (2019, December 3). The other college debt crisis: Schools are going broke. CNBC.https://www.cnbc.com/2019/12/03/the-other-college-debt-crisis-schoolsare-going-broke.html

Government of India (2020). National Education Policy. https://www.education.gov.in/ sites/upload_files/mhrd/files/NEP_Final_English_o.pdf

Goyal, M. (2014, May 11). Ashoka University: India's answer to the Ivy League, promises 'world-class' liberal arts education. The Economic Times. https:// economictimes.indiatimes.com/industry/services/education/ashoka-universityindias-answer-to-the-ivy-league-promises-world-class-liberal-arts-education/ articleshow/34936735.cms

Gupta, U. D. (2002). In pursuit of a different freedom: Tagore's world university at Santiniketan. India International Centre Quarterly, 29(3/4), 25-38.

Ikeda, D. (1992). Gandhism speech at National Museum, New Delhi. https://www. daisakuikeda.org/sub/resources/works/lect/lect-o3.html

Kazmin, A. (2018, March 8). Ashoka University: Ivy League, Indian-style. Financial Times. https://www.ft.com/content/b8fabc8c-1559-11e8-9c33-02f893d6o8c2

Krishnamurti, J. (1953). Education and the significance of life. HarperCollins.

Kumar, K. (2019, July 20). The NEP and liberal arts education. The Hindu. https:// www.thehindu.com/opinion/lead/the-nep-and-liberal-arts-education/ article28598678.ece

Grange, L. L. (2012). Ubuntu, ukama, environment and moral education. Journal of Moral Education, 41(3), 329-340.

Mino, T. (2020a). Humanizing higher education: Three case studies in Sub-Saharan Africa. International Journal of African Higher Education, 7(1), 69-95.

Mino, T. (2020b). Institutional mentorship in West Africa: Comparing governmentregulated and university-led models. Research in Educational Administration \& Leadership, 5(3), 840-868.

Mino, T., \& Heto, P. P.-K. (2020). Educating Humans. Journal of Interdisciplinary Studies in Education, 9, 33-55.

Mohanty, S. B. (2019). Theory and practice of integral education. UNIVERSITY NEWS, 57(33), 11-16. 
Nanda, P. K. (2020, September 2). Only 2 Indian varsities among the world's top 400: THE World University Rankings. Mint. https://www.livemint.com/education/ news/only-2-indian-varsities-among-the-world-s-top-400-the-world-universityrankings-11599048715517.html

Nandrajog, S. (2016, September 27). Student life in Ashoka University: It feels like a second home. Youth Ki Awaaz. https://www.youthkiawaaz.com/2016/o9/life-inashoka-university/

Nussbaum, M. C. (1998). Cultivating humanity. Harvard University Press.

Rao, S. (2020, June 25). Ashoka University - Of the elite, for the elite, by the elite. The ArmChair Journal. https://armchairjournal.com/ashoka-university-of-the-elitefor-the-elite-by-the-elite/

Roche, M. W. (2010). Why choose the liberal arts? University of Notre Dame Press.

Rothblatt, S. (2003). The living arts: Comparative and historical reflections on liberal education. The academy in transition.

Sharma, N. (2021, February 23). From Buddha to Tagore and Gandhi: Valuecreating curricula in India. Oxford Research Encyclopedia of Education. Retrieved 9 Mar. 2021, from https://oxfordre.com/education/view/10.1093/ acrefore/9780190264093.001.0001/acrefore-9780190264093-e-1138.

Sra, G. (2015, March 26). India's new Ivy League. Open The Magazine. https:// openthemagazine.com/features/india/indias-new-ivy-league/

Sykes, M. (1988). The story of Nai Talim.

Symbiosis International University. (2020). Symbiosis International (Deemed University). https://siu.edu.in/symbiosis-international-university.php

Symbiosis School of Liberal Arts. (2021). Financials. https://www.ssla.edu.in/financial

Tagore, R. (1924). The parrot's training.

Van der Wende, M. (2011). The emergence of liberal arts and sciences education in Europe: A comparative perspective. Higher Education Policy, 24(2), 233-253.

World Bank. (2017). Higher education for development: An evaluation of the World Bank Group’s support.

Yang, R. (2016). The East-West Axis? Liberal arts education in East Asian universities. In I. Jung, M. Nishimura, \& T. Sasao (Eds.), Liberal arts education and colleges in East Asia: Possibilities and challenges in the global age (pp. 27-37). Springer. https://doi.org/10.1007/978-981-10-0513-8_3 